\title{
PERBANDINGAN ROUTING PROTOCOL EXTERIOR BGP VERSI 4 DENGAN ROUTING INTERIOR EIGRP PADA ALGORITMA LINKSTATE MENGGUNAKAN PARAMETER PACKET LOSS
}

\author{
Muhammad Ikhsan Azhari ${ }^{1}$, Tengku Mohd. Diansyah ${ }^{2}$, Ari Usman ${ }^{3}$ \\ ${ }^{1,2,3}$ Program Studi Teknik Informatika Fakultas Teknik dan Komputer \\ Universitas Harapan, Medan \\ J1. HM Jhoni No.70 Medan \\ ihsanazhari8@gmail.com,dian.10.22@gmail.com, ariusman09@gmail.com
}

\begin{abstract}
Computer networks very influential on the speed of transferring data from one computer to another computer by using a PC or server, in this case, the routing configuration is very influential. The best routing route selection is the solution to determine the most rapid and efficient routing, and as the best routing consideration, the researcher has examined two routings, namely BGP (Border Gateway Protocol) routing and EIGRP (Enhanced Interior Gateway Routing Protocol) using the Cisco Paket Traccer application. After the researcher was done an experiment, the researcher gets the result of the average EIGRP delay that is 54.619 and the packet loss result between EIGRP and BGP is not available (successful packet delivery).
\end{abstract}

Keywords - BGP Routing Protocol Exterior, EIGRP Interior Routing, Algorithm Link state, Packet loss

Abstrak - Jaringan komputer sangat berpengaruh pada kecepatan transfer data antar satu komputer ke komputer lain baik itu $p c$ maupun server, dalam hal ini konfigurasi routing sangat berpengaruh. Pemilihan jalur routing terbaik merupakan solusi untuk menentukan routing yang paling cepat dan efisien, dan sebagai bahan pertimbangan routing terbaik penulis meneliti dua routing yakni routing BGP (Border Gateway Protocol) dan routing EIGRP (Enhanced Interior Gateway Routing Protocol) mengguanakan aplikasi Cisco Packet Traccer. Setelah dilakukannya percobaan yang penulis perbuat, maka didapatkan hasil dari rata-rata delay EIGRP yaitu 54,619 dan hasil dari packetloss antara EIGRP dan BGP tidak ada (pengiriman paket sukses).

Kata Kunci - Routing Protocol Exterior BGP, Routing Interior EIGRP, Algoritma Link state, Packet loss.

\section{PENDAHULUAN}

Di era perkembangan saat ini teknologi komputer semakin kian pesat tidak terlepas pada perkembangan dunia routing saat ini. Routing yang bertujuan pada proses pengiriman data yang nantinya meneruskan paket daya yang dikirim dari suatu jaringan ke jaringan yang lain. Dalam penerapan untuk menghubungkan beberapa komputer maka komputer tersebut di hubungkan melalui router untuk memberikan akses jalan data yang nantinya berfungsi sebagai menganalisis paket data yang masuk kedalamnya. Paket data yang masuk kemudian akan melewati skema penyeleksian untuk menentukan jalur paling optimal untuk mengirimkan data dari satu jaringan ke jaringan lainnya.

Merupakan sebuah proses untuk meneruskan paket data jaringan menjadi satu network yang nantinya dapat terhubung melalui setiap router sehingga dapat mencakup satu sama lain. Untuk dapat melakukan aktivitas routing dalam suatu jaringan, membutuhkan sebuah router dimana nantinya router sebagai alat perantara atau hardware sehingga proses routing bisa dilakukan dengan tujuan dimana host-host lainnya bisa berkomunikasi dengan host-host yang lain.[8]
RIP merupakan sistem dari routing protocol yang menggunakan metode triggered update. Dalam cakupannya, RIP sendiri mengirimkan routing table yang lengkap dan aktif ke semua interface dalam setiap 30 detik. Dalam penggunaan RIP, routing ini hanya menggunakan jumlah hop untuk menentukan cara terbaik ke sebuah network remote, akan tetapi RIP secara default memiliki sebuah nilai jumlah hop maksimum yg diizinkan yaitu 15 , berarti nilai 16 tidak terjangkau (unreachable), protokol ini menggunakan algoritma Distance-Vector Routing.[2]

EIGRP adalah protokol yang termasuk dalam Interior Gateway Protocol yang menggunakan Autonomous System. Pada jaringan WAN yang besar seperti internet sering terjadi jaringan dibagi menjadi jaringan-jaringan kecil yang disebut autonomous system, setiap autonomous system mengatur daerahnya sendiri.[3]

Routing protocol exterior BGP ini juga merupakan protocol routing standart yang bertujuan untuk memilih jalur interdomain yang berdasarkan path vector protocol. Fungsi utama dari routing ini adalah mempertukaran network reachability information antara BGP router dengan router BGP yang lainnya.[4] 


\section{A. Jaringan Komputer}

Merupakan kumpulan dari beberapa komputer yang dihubungkan satu dengan lainnya untuk berbagi informasi dan perangkat yang ada baik perangkat keras ataupun perangkat lunak. Sebuah jaringan biasanya terdapat berbagai perangkat keras(Hardware) dan perangkat lunak(Software) dimana setiap masing masing perangkat tersebut dapat terhubung satu sama lain yang bertujuan menghasilkan input ataupun output.[5]

\section{B. Protokol Jaringan Komputer}

Jaringan komputer dapat didefinisikan sebagai sekumpulan komputer yang saling berhubungan. Jaringan komputer dapat terdiri dari dua station, atau lebih. Kumpulan komputer tersebut dihubungkan menggunakan perangkat jaringan lainnya.[6]

Dalam dunia komputer, Protokol bisa di artikan sebagai aturan. Sedangkan Protokol Jaringan Komputer yakni aturan berbagai macam device yang saling berkomunikasi dalam sebuah ruang lingkup jaringan. Berbagai macam protokol jiga biasanya sudah kita ketahui diantaranya IPv4 dan DHCP.[7]

\section{Routing}

Merupakan sebuah proses untuk meneruskan paket data jaringan menjadi satu network yang nantinya dapat terhubung melalui setiap router sehingga dapat mencakup satu sama lain. Untuk dapat melakukan aktivitas routing dalam suatu jaringan, membutuhkan sebuah router dimana nantinya router sebagai alat perantara atau hardware sehingga proses routing bisa dilakukan dengan tujuan dimana host-host lainnya bisa berkomunikasi dengan host-host yang lain.[8]

\section{EIGRP}

EIGRP yakni versi lanjutan dari IGRP, yang menawarkan efisiensi operasi yang lebih dari versi sebelumnya. EIGRP merupakan distance vector protocol yang merawat satu set metric yang kompleks untuk jarak tempuh network-networklain. EIGRP juga menggabungkan sebuah konsep protocol yaitu link state protocol. Setiap saat Broadcast-broadcast diupdate yang nantinya ke semua EIGRP router yang berdekatan. Setiap update dari broadcast hanya memasukkan perubahan network dimana EIGRP ini sendiri sangat cocok untuk network-network besar. Adapun EIGRP ini juga menggunakan konsep Diffusing Update Algorithm (DUAL) sebagaimana untuk mendapatkan jalan terbaik ke tujuannya. Dalam mekanisme Kerja EIGRP, jenis routing ini melakukan sebuah proses untuk mencari rute terbaik dengan menghasilkan beberapa informasi tabel, dalam beberapa tabel tersebut diantaranya yaitu tabel, tabel dan tabel routing. Pada saat topologi pertama dibuat, EIGRP mengenali router lain dimana interface yang terhubung langsung ke router tetangga memiliki distance nol dan akan bertambah jika telah berpindah ke router tetangga selanjutnya.

\section{E. BGP (Border Gateway Protocol)}

Border Gateway Protocol merupakan sebuah protocol routing dengan tujuan untuk memilih jalur inter domain yang berdasarkan pada sistem path vector protokol. Fungsi utama BGP yaitu mempertukarkan network reachability information antara BGP router dengan router BGP lainnya. Autonomous system merupakan suatu set routing dalam domain yang dikelola oleh satu otoritas sehingga pengaruhnya dapat langsung diketahui oleh router maupun peer - router. Dengan adanya informasi ini, dapat dibentuk grafik dari AS path yang saling terkoneksi sehingga dapat menghindari terjadinya routing loop.

\section{F. Jenis Algoritma Routing}

Jika diliat dari algoritma atau prosesnya, maka protokol routing dapat dibagi menjadi distance vektor, linkstate.[9]

\section{G. Distance Vector}

Distance Vector Protocol ini memberikan informasi kebanyaknya hop kesetiap jaringan tujuan dan dimana arahnya sebuah paket dapat melakukan pencapaiannya ke jaringan tujuan. Selain Algoritma distance vector ini dikenal sebagai sebuah algoritma Bellman-Ford, yang dimana router ini juga mampu untuk melewatkan updates route ketetangganya pada interval rutin dan terjadwal. Setiap tetangga kemudian menerima nilai tujuannya sendiri dan menyalurkan informasi routing ketetangga terdekat. Hasil proses ini merupakan sebuah table yang berisi kumpulan dari semua distance/tujuan kesemua jaringan tujuan.[10]

\section{H. Link State}

Routing ini sendiri merupakan penggunaan dari teknik link state, yang dimana setiap router akan mengumpulkan informasi tentang interface, bandwidth, roundtrip dan lainnya. Kemudian nanti setiap router akan saling melakukan pertukaran informasi, dan hasil nilai yang paling efisien yang akan diambil sebagai jalur dan di masukkan ke dalam table routing.[10]

\section{Packet Loss}

Packet loss merupakan suatu parameter yang menggambarkan suatu kondisi yang menunjukkan jumlah total paket yang hilang, dapat terjadi karena collision dan congestion pada jaringan. [11]

Untuk menghitung packet loss digunakan rumus sebagai berikut :

Packet Loss $=\frac{\text { Packet data yang dikirim-Paket data yang diterima }}{\text { paket data yang dikirim }} \times 100 \%$

Gambar 1. Rumus menghitung nilai packet loss Sumber : (Prastyo, dkk, 2016) 


\section{METODE PENELITIAN}

Penelitian ini dilakukan dengan Uji Laboratorium. Dimulai dari analisis sitem, perancangan jaringan komputer, simulasi dan implementasi.

\section{HASIL DAN PEMBAHASAN}

\section{A. Analisis Sistem}

Analisis sistem ini merupakan kegiatan dari setiap penguraian dari sebuah hasil sistem informasi yang utuh dan nyata dimana kemudaian setiap bagian serta komponen tersebuat di analisa dengan tujuan mengidentifikasi dan mengevaluasi problematika yang muncul serta hambatan-hambatan yang mungkin terjadi, pada analisis sistem ini lebih mengarah kepada suatu solusi perbaikan maupun pengembangan kearah yang lebih baik lagi sesuai dengan kebutuhan serta perkembangannya teknologi.

\section{B. Perancangan Jaringan Komputer}

Pada perancangan jaringan computer ini nantinya akan di buat dan disimulasikan pada aplikasi Cisco Packet Tracer 6.0.1. Adapun contoh gambar Rancangan jaringan yang digunakan sebagai berikut :

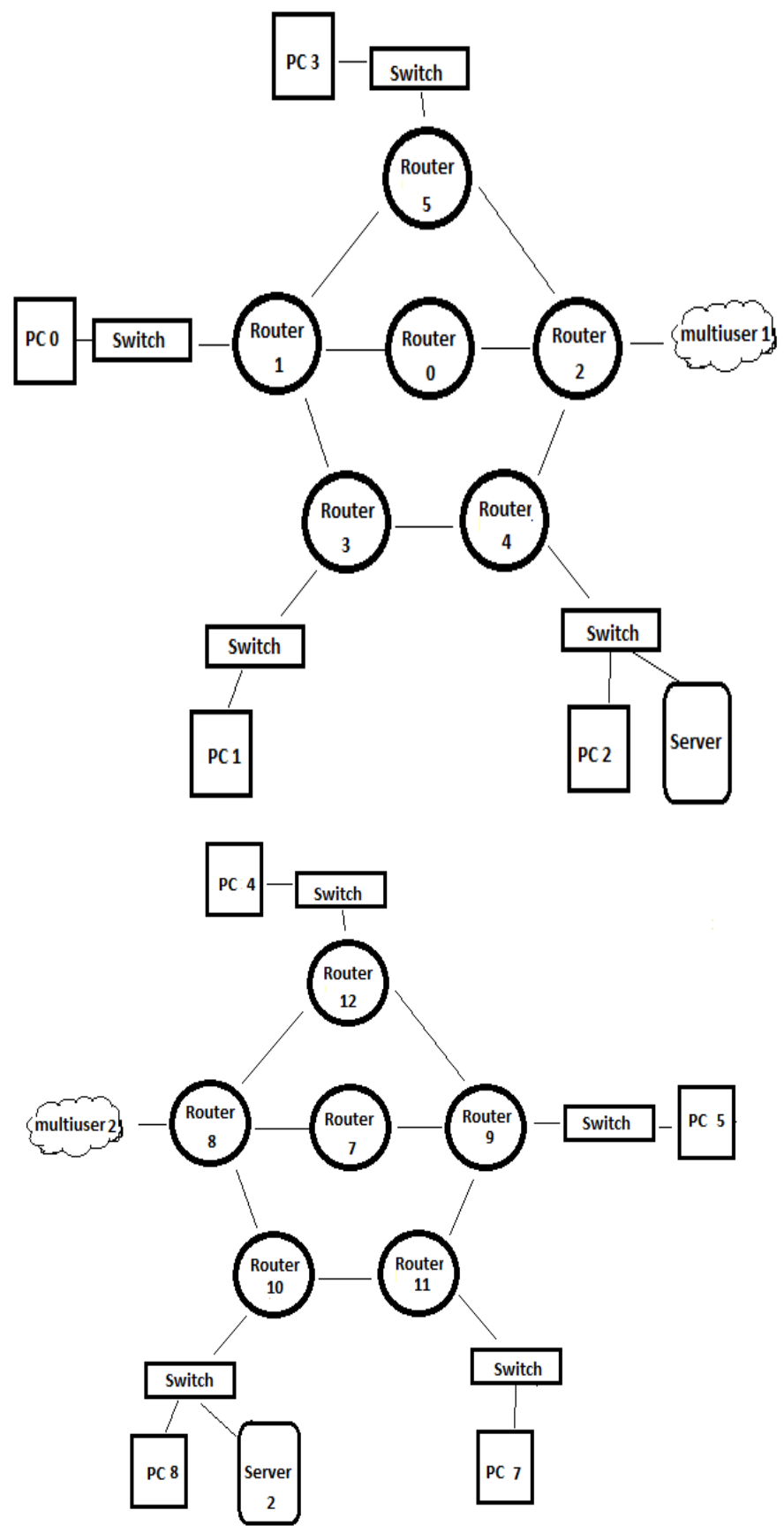

Gambar 1. Rancangan jaringan yang digunakan 


\section{Simulasi Flowchart}

Flowchart juga digunakan yang nantinya berperan sebagai untuk mensimulasikan proses sistem alur kerja.. Pada simulasi ini digambarkan Flowchart yang menjelaskan tentang kinerja routing yang telah penulis analisis.

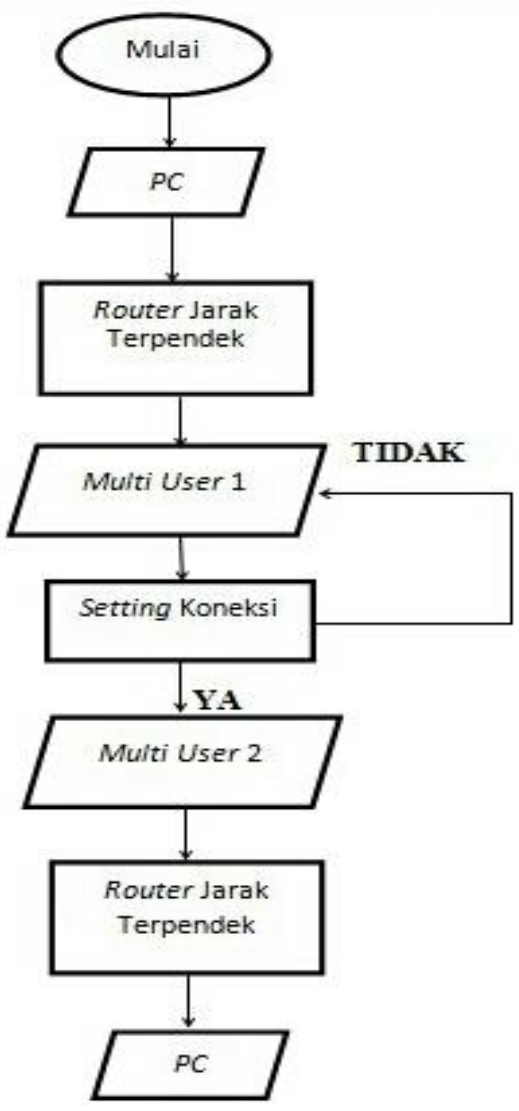

Gambar 2. Simulasi Flowchart Algoritma Linkstate

Sebelum membuat simulasi flowchart algoritm linkstate, penulis telah mendesign flowchart BGP dan EIGRP pada tugas akhir penulis. Pada gambar 2, dijelaskan bahwa pertama kali yang dilakukan ketika mengirim pesan melalui $P C$ kemudian masuk ke router dengan cost yang terkecil atau jarak terpendek lalu masuk ke multiuser dimana multiuser 1 menyambungkan antara multiuser 2 melalui proses konfigurasi koneksi dan kemudian masuk router dengan cost terkecil atau router jarak terpendek, kemudian masuk ke $P C$ tujuan.

\section{Perencanaan IP Address}

Perancangan simulasi jaringan computer tidak terlepas pula dengan IP Address yang bertujuan sebagai pengalamatan agar $P C$ dapat terhubung dan dapat pula mengenal $P C$ lainnya sehingga paket data tidak bentrok dan mengakibatkan Request Time Out. Pada perancangan IP Address, Penulis menggunakan IP Address Kelas A, B dan C.

\section{E. Analisis Routing}

Setiap routing memiliki konfigurasi yang berbeda dan banyak pula jenisnya, untuk itu penulis melakukan rancangan konfigurasi routing BGP dan EIGRP yang nantinya proses konfigurasi akan ditampilkan sesuai dengan apa yang telah penulis analisa berdasarkan yang penulis kerjakan.

\section{F. Analisis Packet Loss}

Packet Loss merupakan sebuah parameter yang menunjukkan suatu paket data yang tidak terlihat atau hilang karena disebabkan oleh beberapa hal yang menjadi kinerja paket terhambat.

Tabel 1. Kategori pada Packet Loss

\begin{tabular}{|c|c|c|}
\hline Kategori Degradasi & Packet Loss & Indeks \\
\hline Sangat Bagus & $0 \%-2 \%$ & 4 \\
\hline Bagus & $3 \%-14 \%$ & 3 \\
\hline Sedang & $15 \%-24 \%$ & 2 \\
\hline Buruk & $>25 \%$ & 1 \\
\hline
\end{tabular}

Sumber : (Villasica\&Mubarakah, 2014)

Pada table 1 menunjukkan dan dijelaskan kategori Degradasi yang sangat bagus itu terdapat di Packet Loss dari 0\%-2\% dengan indeks 4, sedangkan kategori degradasi dengan kata bagus terdapat di Packet Loss 3\%-14\% dengan indeks 3, seterusnya semakin sedikit kategori Packet Loss maka semakin bagus dan semakin besar Packet Loss maka semakin buruk.

Tabel 2. Packet Loss

\begin{tabular}{|c|c|c|c|}
\hline $\begin{array}{c}\text { Node } \\
\mathrm{Ke}\end{array}$ & Packet Dikirim & Packet Diterima & Packet Loss (0\%) \\
\hline Server & 5 & 5 & 0 \\
\hline PC 4 & 5 & 5 & 0 \\
\hline PC 5 & 5 & 5 & 0 \\
\hline PC 6 & 5 & 5 & 0 \\
\hline PC 8 & 5 & 5 & 0 \\
\hline \multicolumn{2}{|c|}{ Packet Loss Keseluruhan } & $0 \%$ \\
\hline
\end{tabular}

Untuk menghitungPacket Loss digunakan rumus sebagai berikut

Packet Loss $=$

$$
\frac{\text { Packet data yang dikirim - Paket data yang diterima }}{\text { paket data yang dikirim }} \times 100 \%
$$

Packet Loss $=\frac{5-5}{5} \times 100 \%=0 \%$, jadi koneksi routing memiliki predikat sangat bagus karena packet loss $0 \%$.

\section{G. Implementasi Simuasi Jaringan}

Implementasi simulasi pada perancangan jaringan ini menggunakan perangkat lunak Cisco Packet Traccer dimana proses pengujian serta konfigurasi routing BGP dan routing EIGRP ini dilakukan. Pada 
konfigurasi routing tersebut, penulis menggunakan commendline.

\section{H. Implementasi Routing BGP}

Adapun rancangan topologi BGP dalam penggunaan multiuser sebagai berikut :

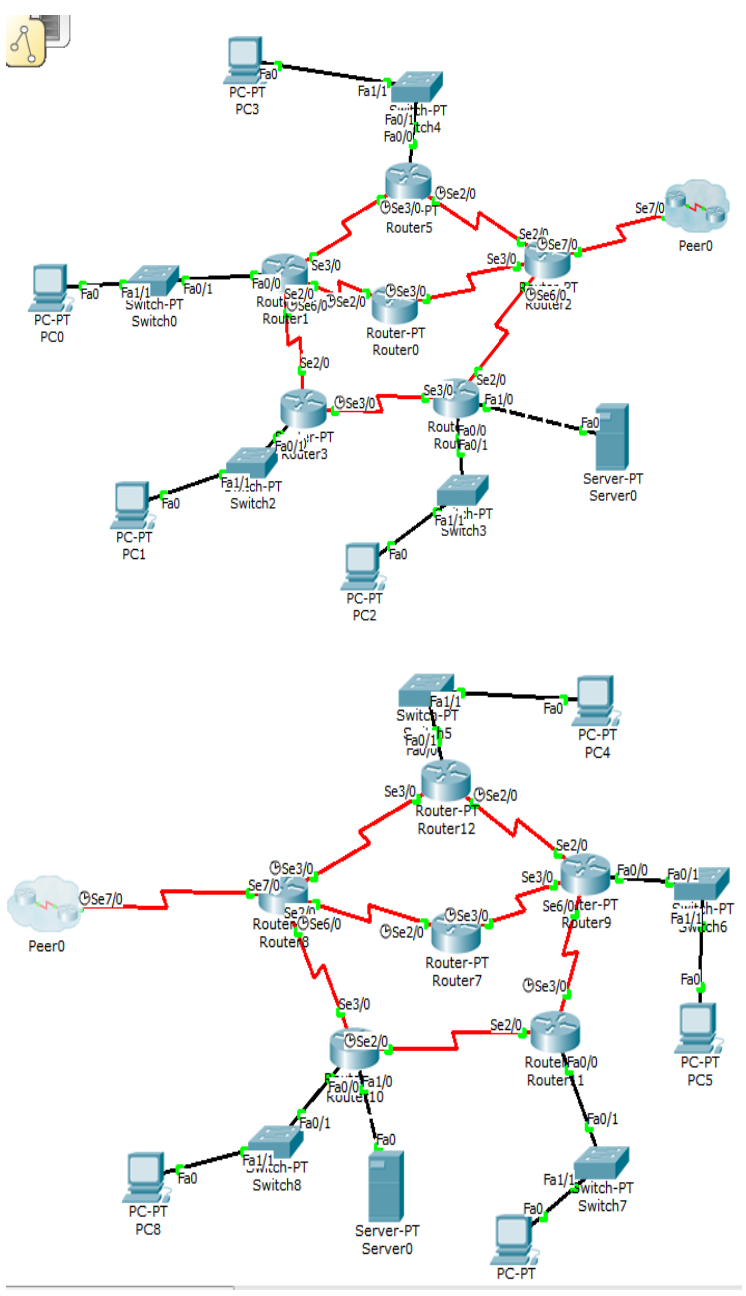

Gambar 3. Hasil Rancangan Topologi Routing BGP

Pada gambar 3 terdapat $8 P C$ dan 2 Server yang dibagi menjadi 2 kelompok yang nantinya akan saling terhubung, sehingga setiap komputer dan server dapat berinteraksi satu sama lain. Dalam rancangan ini menggunakan konfigurasi routing BGP.

\section{Implementasi Routing EIGRP}

Adapun rancangan topologi BGP dalam penggunaan multiuser sebagai berikut :

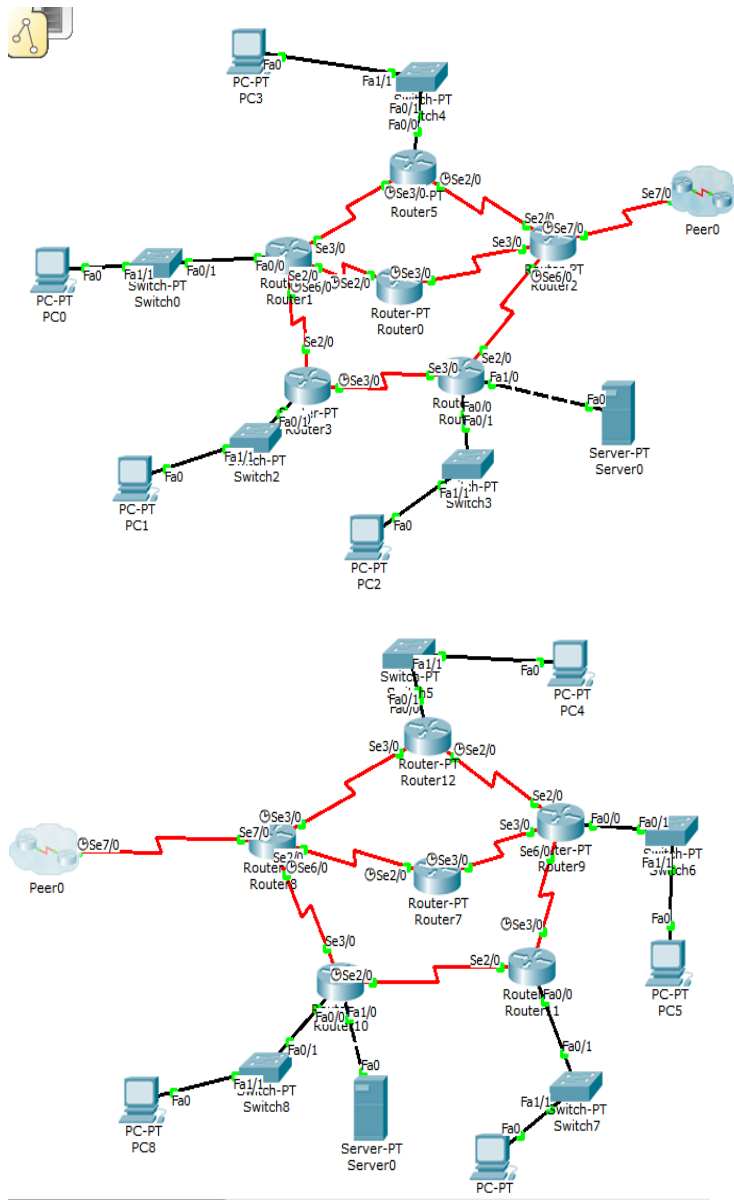

Gambar 4. Hasil Rancangan Topologi Routing EIGRP

Dalam Gambar 3 ini juga terdapat $8 P C$ dan 2 Server yang dibagi menjadi 2 kelompok yang nantinya akan saling terhubung, sehingga setiap Komputer dan Server dapat berinteraksi satu sama lain. Sama halnya seperti topologi BGP dalam Gambar 3.5, hanya saja dalam rancangan ini menggunakan konfigurasi routing EIGRP.

\section{J. Tabel Pengujian}

Setelah melalukan pengujian simulasi terhadap routing BGP dan EIGRP. Maka, penulis telah menyimpulkan hasil dari pengujian yg penulis buat. Pada tabel pengujian akan dihitung nilai delay dan packetloss terhadap routing BGP dan EIGRP.

Tabel 3. Delay EIGRP

\begin{tabular}{|c|c|c|c|c|c|}
\hline \multicolumn{5}{|c|}{ C } & Delay \\
\hline Server & PC 4 & PC 5 & PC 6 & PC 8 & Rata-rata \\
\hline 55,158 & 55,323 & 54,141 & 54,092 & 54,382 & 54,619 \\
\hline \multicolumn{5}{|c|}{ DelayKeseluruhan } & 273,096 \\
\hline
\end{tabular}


Berdasarkan dari tabel 3 jumlah paket yang di kirim sebanyak 5 paket. Pengujian dilakukan secara berurut ke setiap $P C$ maupun Server.

Adapun rumus untuk mencari rata-rata delay:

Rata Rata Delay = Total Delay / Total Paket Yang DiTerima

$$
\begin{aligned}
& =273,096 / 5 \\
& =54,619
\end{aligned}
$$

Tabel 4. Packet Loss BGP

\begin{tabular}{|c|c|c|c|}
\hline C & Packet Dikirim & Packet Diterima & Packet L oss (0\%) \\
\hline Server & 5 & 5 & 0 \\
\hline PC 4 & 5 & 5 & 0 \\
\hline PC 5 & 5 & 5 & 0 \\
\hline PC 6 & 5 & 5 & 0 \\
\hline PC 8 & 5 & 5 & $0 \%$ \\
\hline \multicolumn{3}{|c|}{ Packet Loss Keseluruhan } \\
\hline
\end{tabular}

Berdasarkan Tabel 4 jumlah packet loss yang di terima sebanyak $0 \%$. Packet yang dikirm sebanyak 5 kali dari hasil pengiriman tidak ada Packet Loss yang tertera.

Packet Loss $=\frac{\text { Packet yang dikirim-Paket data yang diterima }}{\text { paket data yang dikirim }} \mathrm{x}$ $100 \%$

Packet Loss $=\frac{5-5}{5} \times 100 \%=0 \%$, jadi koneksi routing memiliki predikat sangat bagus karena Packet Loss $0 \%$.

Tabel 5. Packet Loss EIGRP

\begin{tabular}{|c|c|c|c|}
\hline $\begin{array}{c}\text { Node } \\
\text { Ke }\end{array}$ & Packet Dikirim & Packet Diterima & Packet L oss (0\%) \\
\hline Server & 5 & 5 & 0 \\
\hline PC 4 & 5 & 5 & 0 \\
\hline PC 5 & 5 & 5 & 0 \\
\hline PC 6 & 5 & 5 & 0 \\
\hline PC 8 & 5 & 5 & 0 \\
\hline \multicolumn{3}{|c|}{ Packet Loss Keseluruhan } \\
\hline
\end{tabular}

Berdasarkan Tabel 5 jumlah Packet Loss yang di terima sebanyak 0\%. Packet yang dikirm sebanyak 5 kali dari hasil pengiriman tidak ada Packet Loss yang tertera. Adapun rumus mencari Packet Loss :

Packet Loss $=$

Packet data yang dikirim-Paket data yang diterima $\times 100 \%$ paket data yang dikirim

Packet Loss $=\frac{5-5}{5} \times 100 \%=0 \%$, jadi koneksi routing memiliki predikat sangat bagus karena Packet Loss $0 \%$.

\section{K. Hasil Perbandingan}

Dari tabel pengujian yang dilakukan maka dapat diambil kesimpulan untuk melihat kinerja routing yang mana yang lebih baik antara BGP dan EIGRP. Adapun hasil perbandingan dapat dilihat dari tabel 6 .

Tabel 6. Hasil Pengujian Routing

\begin{tabular}{|c|c|c|}
\hline Jenis Routing & Rata-Rata Delay & Rata-Rata Packet Loss \\
\hline BGP & $\cdot$ & $0 \%$ \\
\hline EIGRP & 54,619 & $0 \%$ \\
\hline
\end{tabular}

Selanjutnya penulis melakukan penganalisisan untuk mencari buffer terhadap kedua routing.

Hasil dari analisis kedua routing tersebut dapat dilihat pada tabel 7 dan tabel 8 .

Tabel 7. Hasil buffer pada routing BGP

\begin{tabular}{|c|c|c|c|c|}
\hline \multicolumn{5}{|c|}{ Buffer BGP } \\
\hline Ke PC4 & KePC5 & Ke PC6 & Ke PC8 & Ke Server \\
\hline 77,422 & 76,328 & 71,598 & $79,65 !$ & 73,778 \\
\hline
\end{tabular}

Pada tabel 7 terlihat tampilan hasil pengiriman packet pada routing BGP dimana setiap setiap pengiriman packet data berbeda-beda dan pada nilai buffer yang juga berubah-ubah.

Tabel 8. Hasil buffer pada routing EIGRP

\begin{tabular}{|c|c|c|c|c|}
\hline \multicolumn{5}{|c|}{ BufferEIGRP } \\
\hline Ke PC4 & KePC5 & Ke PC6 & KePC8 & Ke Server \\
\hline 55,323 & 54,141 & 54,092 & 54,382 & 55,175 \\
\hline
\end{tabular}

Pada table 8 terlihat tampilan hasil pengiriman packet pada routing EIGRP dimana setiap setiap pengiriman packet data berbeda-beda dan pada nilai buffer yang juga berubah-ubah.

\section{KESIMPULAN DAN SARAN}

Berdasarkan hasil pengujian yang dilakukan berdasarkan simulasi jaringan Cisco Packet Traccer menggunakan protocol routing BGP (Border Gateway Protocol) dan protocol routing EIGRP (Enhanced Interior Gateway Routing Protocol) diatas, maka kesimpulannya sebagai berikut :

1. Konfigurasi pada EIGRP lebih efisien serta lebih mudah untuk dilakukan dibandingkan dengan konfigurasi BGP.

2. Pada transfer file/pengiriman data pada topologi EIGRP, rata-rata total waktu delay yang telah didapatkan dalam proses simulasi adalah 54,619. 
Serta Packetloss yang di dapatkan pada EIGRP yaitu $0 \%$ dan Packet Loss yang didapat pada BGP juga $0 \%$.

3. Jumlah keseluruhan delay pada EIGRP adalah 273,096.

4. Kecepatan Tranfer data pada setiap masing router berbeda-beda dengan selang waktu keseluruhan EIGRP yaitu 273,096/sec sedangkan BGP yaitu $385,053 /$ sec.

Setelah melakukan penelitian dari hasil tugas akhir yang telah diperbuat penulis, ada baiknya dilakukan simulasi terlebih dahulu untuk meninjau kinerja routing agar peneltian dapat berjalan dengan baik. Dan sebagai bahan pertimbangan, penulis menyarankan penggunaan routing EIGRP karena lebih efisien dalam pengkonfigurasian serta kecepatan yang lebih baik dibandingkan dengan BGP.

\section{Daftar Pustaka}

[1] J. A. Allen, "Perancangan Routing Protocol di Jaringan PT.Kawanua internetindo," Peranc. routing Protoc. di Jar. PT.Kawanua internetindo, vol. 4, p. 23, 2015.

[2] S. Wardoyo, "Analisis Performa File Transport Protocol pada Perbandingan Metode IPv4 Murni, IPv6 Murni dan Tunneling 6to4 Berbasis Router Mikrotik," Anal. PERFORMA FILE Transp. Protoc. PADA PERBANDINGAN Metod. IPv4 MURNI, IPv6 MURNI DAN TUNNELING 6to4 Berbas. ROUTER MIKROTIK, vol. 3, pp. 109-110, 2014.

[3] A. H. Lubis, "Analisis Routing EIGRP dalam Menentukan Router yang dilalui pada WAN," Anal. Routing EIGRP dalam Menentukan Router yang dilalui pada WAN, vol. 1, p. 24, 2017.

[4] Y. D. Villasica, "ANALISIS KINERJA ROUTING DINAMIS DENGAN TEKNIK OSPF (OPEN SHORTEST PATH FIRST) PADA TOPOLOGI MESH DALAM JARINGAN LOCAL AREA NETWORK (LAN) MENGGUNAKAN CISCO PACKET TRACER," vol. 7, p. 126, 2014

[5] P. Soepomo, "ANALISIS DAN OPTIMALISASI JARINGAN MENGGUNAKAN TEKNIK LOAD BALANCING ( Studi Kasus: Jaringan UAD Kampus 3 )," vol. 2, pp. 1370-1378, 2014.

[6] T. Komputer, S. Teknik, and S. Itb, "Jurnal Teknik Komputer Unikom Komputika - Volume 3, No.1 - 2014,” vol. 3, no. 1, pp. 31-37, 2014.

[7] Dini, "Protokol Jaringan pada Jaringan Komputer," pp. 1-10, 2015.

[8] F. U. Hasanah, N. Mubarakah, K. K. Lan, T. Ring, R. D. Rip, and C. P. Tracer, "ANALISIS KINERJA ROUTING DINAMIS DENGAN
TEKNIK RIP ( ROUTING INFORMATION PROTOCOL ) PADA TOPOLOGI RING DALAM JARINGAN LAN ( LOCAL AREA NETWORK ) MENGGUNAKAN CISCO PACKET TRACER," vol. 7, no. 3, pp. 118124, 2014.

[9] M. T. Putu Agus Eka Pratama, S.T., Handbook Jaringan Komputer. Bandung, 2015.

[10] F. Yusuf Mochamad and Y. Soepriyanto, "Rancang Bangun Animasi Protokol Routing Jenis Distance Vector dan Link State Menggunakan Teknologi Augmented Reality," Semin. Nas. Inov. Teknol., vol. 1, no. 1, pp. 1116, 2017.

[11] E. Prasetyo, A. Hamzah, and E. Sutanta, "Jurnal JARKOM Vol . 4 No . 1 Desember 2016 ISSN : 2338-6313 ANALISA QUALITY OF SERVICE ( QOS ) Jurnal JARKOM Vol . 4 No . 1 Desember 2016 ISSN : 2338-6313," vol. 4, no. 1, pp. 29-37, 2016. 